director, Regional Transfusion and ImmunoHaematology Centre); B. Moore-Smith, B.M.,
M.R.C.P. (consultant physician in geriatrics, Ipswich M.R.C.P. (consultant physician in geriatrics, Ipswich F.R.C.S. (consultant surgeon, Norwich, Lowestoft, F.R.C.S. (consultant urological surgeon, Norfolk and Norwich a rea)

Manchester Regional Hospital Board.-N. $\mathrm{H}$. Mahindrakar, M.B., F.R.C.S., D.L.O. (whole-time or maximum part-time consultant E.N.T. surgeon, Bolton and District group of hospitals).
MINISTRY OF OVERSEAS DEVELOPMENT.-G. B. Ministry OF OVERSEAS DEVELOPMENT.-G. B.
Smart, M.B., D.P.H. (chief medical officer, GovernSmart, M.B., D.P.H.

NewCASTIE REGIONAL Hospital BoARD.-M. Mehta, M.B., F.F.A. R.C.S. (consultant in anaesBarwick, M.B., M.R.C.P.Ed. (consultant in D. D. logy, Newcastle) ; I. B. Porteous, M.B., M.C.Path (consultant in pathology, North and West Durham); E. H. Jarvis, B.M.

geriatrics, Newcastle).
NORTHERN IRELAND Hospitals AUTHORITY.-R Armstrong, M.B., F.F.A.R.C.S., and R. C. Hamilton, M.B., F.F.A. R.C.S.I. (consultant anaesthetists, Ulster group); J. H. Connolly, M.D.j,
M.R.C P.I., M.C.Path. (consultant virologist, BelM.R.C P.I., M.C.Path. (consultant virologist, Beland North Down groups); J. D. H. Mahony, M.D., M.R.C.P.Glasg., D.C.H. (consultant venereologist, Belfast group); P. S. Thomas, M.B.,
F.F.R., D.M.R.D. (consultant radiologist, Belfast F.F.R., D.M.R.D. (consultant radiologist, Belfast
group); F. R. Wright, M.B., F.F.R., D.M.R.D.
(consultant radiologist, Ulster and North Down (consultant radiologist, Ulster and North Down
groups).

BOARD-G. G. Farrington, M.B., F.R.C.S.Ed. (consultant orthopaedic surgeon to Thames group (consultant physician to the Southend-on-Sea group and Runwell Hospital); L. Klenerman, M.B. F.R.C.S. (consultant orthopaedic and traumatic surgeon to Tottenham group of hospitals); M. P.
Nelson, M.R.C.S., D.P.M. (consultant psychiatrists (physician superintendent) to Royal Eastern Counties group of hospitals); D. S. Orr, M.B., F.F.A of hospitals).

North-West Metropolitan Regional Hosprtal BOARD.-Margaret O. Hunt, M.R.C.S., D.A. (consultant anaesthetist at Willesden General Hospital) surgeon at Wexham Park, King Edward VII, and Maidenhead Hospitals); R. Hoffenberg, M.D.
M.R.C.P. (consultant physician at New End HospiM.R.C.P. (consultant physician at New End Hospiphysician (medical assistant grade) for the geriatric service in the Luton area).

NOTTINGHAMSHIRE COUNTY COUNCIL.-H. I OXFORD REGIONAL HOSPITAL BOARD.-R. A Griffiths, B.M., M.R.C.P. (consultant in general medicine, with special interest in geriatrics, Oxford/ sultant psychiatrist, Swindon/Cirencester area) I. M. Phalke, M.B., D.M.R.E. D.M.R.D. (consultant radiologist, Princess Margaret Hospital, SOUTH-EAST METROPOLITAN REGIONAL, HOSPITA
BOARD.-Florence Obadiah, M.B. F.F.A.R.C.S (consultant in anaesthetics, Medway and Gravesend group); J. H. P. Willis, M.B., M.R.C.P., D.P.M (consultant in psychiatry, Bexley group); A. G. N
Clark. M.D., M.R.C.P. (consultant in geriatrics,
Brighton and Lewes and Mid-Sussex groups) ; D. A. Packham, M.B., F.R.C.S. (consultant in urology, D. J. Reid, D.M.' M.Ch., F.R.C.S. (consultant in groups); Mrighton and Lewes and MidM.R.C.O.G. (consultant in obstetrics and gynaecoM.R.C.O.G., D.C.H. (consultant in obstetrics and gynaecology (Bromley group)); D. A. Young, M.B., F.F.A.R.C.S. (consultant in anaesthetics, Bromley Group); J. R. Cobbett, M.B., F.R.C.S. Lewisham groups); D. A. Pyke, M.D., F.R.C.P. (consultant in general medicine, Tunbridge Wells
group). SOUTH-WESTERN REGIONAL HOSPITAL BOARD.group, Bristol) ; D. A. Sime, M.B., D.P.M. (consultant psychiatrist (subnormality) Cornwall and Langdon Hospital); D. H. Yates, M.B.. D.P.M. (consultant psychiatrist, West Cornwall clinical area,
based at St. Lawrence's Hospital). based at St. Lawrence's Hospital).
UNITHD Manchester Hospitals. - W. Jackson, M.B., F.P.A. R.C.S. (whole-time consultant anaesthetist).

\section{Universities and Colleges}

\section{CAMBRIDGE}

M.B.-Lesley A. Farebrother, M. J. B. Fare-
rother, A. G. Gray, *E. J. Barrington-Ward *C. M. Britton, "R. S. Maurice-Williams, F. S Pagan, "Mangaret E. Tompsett, P. B. Wood.

BIRMINGHAM

M.D.-J. G. Jones, "J. Bradiey, M. N. Eade

CH.M. P. Omo-Daré. Rogers, Jennifer A. Stephenson.

The title of university clinical lecturer has been conferred on the following: Dr. J. S. Crawford, consultant anaesthetist, United Birmphysician, United Birmingham Hospitals; Dr. G. Hall-Davies and Dr. J. S. Mather, consultant anaesthetists, United Birmingham Hospitals and the Birmingham Regional Hospital Board.

The title of senior clinical tutor in infectious diseases has been conferred on Dr. R. Fothergill, consultant in infectious diseases, East Birmingham Hospital.

The following have been appointed tutors for dental students: Dr. P. Asquith (medicine); $\mathrm{Mr}$. M. G. S. Golby, Mr. R. T. J. Holl-Allen, Mr. J. N. Kille (general surgery)

The following have been appointed postgradute clinical tutors: Mr. J. D. Hennessey, West Bromwich group of hospitals; Dr. J. A. LitchC. M. Davidson, M.B., M.Ch., F.R.C.S.Ed. (conPH.D. In the Faculty of Medicine : D. Catty, Lavelle. A. L. Awad El-Ganzoury. ingham Hospitals; Dr. P. W. Dykes, consultan

\section{New Issues of Specialist Journals}

Obtainable from the Publishing Manager, B.M.A. House, Tavistock Square, London W.C.1.

\section{T H O R A X}

Contents of the March issue are as follows

The Fate of Preserved Homograft Pericardium and Autogenous Pericardium within the Heart. C. P. Clarke, B. G. Barratt-Boyes, and F. H. Sims.

uccessful Thrombo-embolectomy in Long-standing Thrombo-embolic Pulmonary Hypertension. E. S

Pulmonary Embolectomy Using Normothermic Venous Inflow Occlusion. D. B. Clarke.

Bronchial Carcinoma. B. T. le Roux.

Influence of Pulmonary Vascular Disease and Fibrosis on Prognosis Following Closed Mitral Valvotomy. Rowan Nicks and V. J. McGovern.

Combined Mediastinal and Retroperitoneal Fibrosis. H. W. Salmon.

An Unusual Example of Exercise-induced Asthma. G. K. Crompton.

Some Histological Changes in Chronic Bronchitis and Asthma. G. Salvato.

Total Prosthetic Replacement of Atrioventricular Valves in the Dog. Part I. Development of a Free-floating Cone Valve for the Right Atrioventricular Ostium. G. den Otter. Part II. Development of a Tilting
Total Prosthetic Replacement of Atrioventricular Valves in the Dog. Part Cone Mitral Prosthesis. G. den Otter. Busulphan Lung. B. E. Heard and R. A. Cooke.
Carbon Dioxide in the Prevention of Air Embolism during Open-heart Surgery. W. Shang $\mathrm{Ng}$ and
Michael Rosen.

Rheumatic Mitral Stenosis in Association with Partial Anomalous Pulmonary Venous Return. J. M. Reid, R. S. Barclay, J. G. Stevenson, T. M. Welsh, and N. McSwan

Extralobar Pulmonary Sequestration. A. Olufemi Williams and F. I. Enumah.

Fmergency Oesophagectomy. W. F. Kerr. Koskinen, and S. O. Suurkari.

Chylothorax in Infancy. Woiciech Jeske
Lung Abscess in Childhood. Patricia H. Mark and J. A. Peter Turner.

Volume 23, No. 2. Yearly subscription (6 numbers) $£ 44 \mathrm{~s}$., abroad $£ 415 \mathrm{~s}$. field, Walsall group of hospitals; Dr. B. F. Bowers, Dudley and Stourbridge group of hospitals.

The title of honorary lecturer has been conferred on the following in the departments indlcated in parentheses: Dr. P. W. Dykes, consultant physician, United Birmingham Hospitals (experimental pathology); Dr. K. B. Rogers (baceriology, also virology)

The title of assistant clinical tutor has been conferred on the following in the departments indicated in parentheses for the period of their service in the United Birmingham Hospitals : Dr. R. N. Bale (psychiatry) ; Dr. C. C. Wise (anaesthetics).

\section{SHEFFIELD}

Appointments.-Dr. A. Kennedy (senior lecturer in pathology); Mr. R. H. Baker (part-time honorary chnical tutor, orthopaedics); Mr. J. J. Corkery (part-time honorary clinical tutor, paediatrics); Dr ary demonstrators in medical microbiology); Dr. dental Perks (pare $R$. S Statham (part-time honorary instructor in venereology); Mr. I. M. Strachan part-time clinical teacher in ophthalmology); $\mathbf{M r}$. A. K. Yates (part-time clinical teacher in cardiothoracic surgery).

\section{Corrections}

Deaths from Asthma.-In the letter by $\mathrm{Dr}$. I. W. B. Grant (2 March, p. 575) the second and third lines of the second paragraph should have read ". . . it would be most unwise for any doctor to permit his patients to use these powerful drugs to excess."

In the epidemiological Table of Infectous Diseases and Vital Statistics for the week ending 10 February (2 March, p. 586) the number of deaths from scarlet fever in England and Wales was erroneously recorded as 382 . This referred to the number of cases ; by the Registrar General.

\section{Notice to Authors}

When original articles and letters for publication are not submitted exclusively to the Brittsh Medical fournal this must be stated.

Correspondence on editorial business should be addressed to the Editor, British Medical Fournal, B.M.A. House, Tavistock Square, London W.C.1. Telephone: 01-387 4499. Telegrams: Aitiology, London W.C.1.

Authors wanting reprints of their ardcles should notify the Publishing Manager, B.M.A House, Tavistock Square, W.C.1, on receipt of proofs.

\section{Subscription}

Members' subscriptions should be sent to the Secretary of the British Medical Association, B. A House, London, or to the Scottish Secretary, B.M.A. Scottish Office, Drumsheugh Gardens, Edinburgh.

Doctors who are not members of the B.M.A can subscribe to the B.M.F. The rates for doctors resident in the United Kingdom and abrodd are given on the first page of the classified advertisements. These include the rates for the Australian edition and the North American " Air Express," which are available to both members and non-members of the B.M.A.

\section{Classified Advertisements}

Doctors Abroad.-Copies of the appointment vacancies advertised in the B.M.f. can be sent by airmail on request. The minimum cost is $3 \mathrm{~s}$. per week, for which copies of vacancies in up to five sections of the classified advertisements will be sent. The cost of each further sectlon after five is 1s. Orders for specific grades In any section cannot be accepted. Payments should be enclosed with the order.

Details of rates, etc., for classified advertisements appear on the first page of the classified section. 